\title{
FAM135B wt Allele
}

National Cancer Institute

\section{Source}

National Cancer Institute. FAM135B wt Allele. NCI Thesaurus. Code C143113.

Human FAM135B wild-type allele is located in the vicinity of 8q24.23 and is approximately $367 \mathrm{~kb}$ in length. This allele, which encodes protein FAM135B, may be involved in cholesterol metabolism. 